\title{
Restorative Justice in Indonesian Law on Juvenile Criminal Justice System and Its Implications for Social Work
}

\author{
Edi Suharto*
}

\author{
Pasundan University, Bandung, Indonesia; Director General of Social Empowerment, Ministry of Social \\ Affairs of the Republic of Indonesia
}

\begin{abstract}
The study was motivated by Indonesian Law on Juvenile Criminal Justice System, which is now starting to take effect based on the restorative justice paradigm. The study aims to analyze the restorative justice in the juvenile system as the settlement of criminal cases together with related parties in order to find a fair settlement by emphasizing restoration to its original state. By using the socio-legal approach, the results recommend that to achieve this restorative justice, efforts are made to diversify or transfer the settlement of juvenile cases from the criminal justice process to the non-criminal court process. It is in this diversion effort that it has an impact on social work. If previously social workers had a small role towards children in conflict with the law $(\mathrm{ABH})$, now their role is bigger. So that it takes an increase in quality and quantity. The results would imply that increasing both quality and quantity must be followed by efforts such as education and training. Practical implications also denote the quality of social welfare service institutions be strengthened because this institution will accommodate $\mathrm{ABH}$ when the diversion effort is agreed upon by the parties.
\end{abstract}

Keywords: Restorative justice, juvenile law, the justice system, social workers.

\section{INTRODUCTION}

The concept of equality before the law has become the main principle in the world of international law, including Indonesia. Justice does not only belong to certain circles but is the right of the whole community, including children. Justice also concerns the fulfillment of children's rights when dealing with the law, both rights in social and psychological life. These rights need to be emphasized because the handling of children who conflict with the law often neglects their rights. Equality before the law in the context of child welfare thus means that children are entitled to justice, especially to get social and psychological rights during the legal process (Khair, 2001). The children's rights need to be considered, because the situation of Indonesian children in conflict with the law $(A B H)$ is still shrouded in serious problems (Davies \& Robson, 2016). Most children do not get their rights properly when they are faced with the law. This situation can be seen from the process of case examination to court decisions that ignore children's rights. For example, in the examination process, most children were detained instead of being suspended. Data from the Directorate General of Corrections as of July 3, 2014 shows that 2,087 children are being held in various detention institutions throughout Indonesia. This figure is increases compared to the population of juvenile detainees in 2011: 1,971 juvenile prisoners await criminal justice proceedings. In terms of court decisions, the University of Indonesia and Unicef

*Address correspondence to this author at the Universitas Pasundan $\mathrm{Jl}$. Wartawan IV No.22, Turangga, Lengkong, Bandung, West Java 40264, Indonesia; E-mail: edisuharto.unpas@gmail.com
Department of Criminology found that 85 percent of children arrested for committing criminal acts will be immediately processed to the prosecution stage, 80 percent of who continue to be investigated at trial, and 61 percent of them sentenced to prison (Amanda, 2014). The child-friendly prison approach is one of the efforts to meet the growth and development needs of children who may be deprived while in prison. This approach is taken because there is no other choice for a child other than to become a criminal in prison. In other words, this approach can be an alternative solution when prison is the only solution to provide treatment for children who are facing the law. This approach is known to be more moderate than the conventional model which places children in prison as adults in general. However, over time, this more moderate approach needs to be modernized so that children's rights can be more secure. Because after all, no matter how friendly the prison is, it is still not an ideal solution because it relies on the principle of retribution, not a return to its restorative state.

Legal handling, especially for children with retributive principles, is believed to be ineffective in making children better. Therefore, legal handling of children today tends to use restorative principles. This is at least the background for the birth of Law Number 11 of 2012 concerning the Child Criminal Justice System (commonly abbreviated SPPA in Indonesian) as a substitute for Law Number 3 of 1997 concerning Juvenile Court. Based on the SPPA Law, it is possible for a child to get a legal settlement out of court because of the concept of restorative justice. Thus, the birth of the SPPA Law is basically a big leap that should be appreciated. Meanwhile, in the current context the 
discussion of the SPPA Law is the right momentum. It should be noted, in accordance with the mandate of the constitution this Law takes effect after 2 years from the date of promulgation. The SPPA Law itself was promulgated since July 30,2012 . Although the SPPA Law still leaves some homework (PR), such as the absence of a Government Regulation (PP), this Law need the preparation for implementation in order to fulfill ABH's rights. This paper examines two main issues related to the SPPA Law. First, how is the concept of restorative justice which is an important issue in the SPPA Law. Restorative justice becomes an important issue because this concept supports children's rights as well as what differentiates it from the previous law. Second, the implications of the SPPA Law on the social work sector. When legal issues are resolved outside the court, $\mathrm{ABH}$ will then become the responsibility of social welfare institutions. This is where the relevance of the application of the SPPA Law has implications for the field of social work.

\section{LITERATURE REVIEW}

\subsection{Restorative Justice}

Restorative justice is an important concept in the SPPA Law, because this concept is a sign of a paradigmatic change compared to the Juvenile Court Law. Restorative justice is understood as the settlement of criminal cases by involving perpetrators, victims, families of the perpetrators/victims, and other related parties to jointly seek a fair settlement by emphasizing restoration to its original state, and not retaliation (SPPA Article 1 Paragraph 6). The changes from Law on Juvenile Court to SPPA revealed an evolutionary paradigm shift. In the first stage, during the validity period of the Juvenile Court Law, the handling of $\mathrm{ABH}$ used the paradigm of retributive justice (retaliation). Child crime is seen in black and white, even though minor forms of child crime must still be repaid with a criminal penalty. The aim is to get a deterrent effect not to restore the original condition (restorative) in children. Detention and imprisonment of children mixed with adult prisons are common cases because they fulfill the element of retaliation for what a child has done as a criminal. The law does not pay attention to the interests of children, its interest is to achieve a deterrent effect. Despite the fact, instead of being able to reap a deterrent effect, the perpetrators get prolonged trauma and even become victims of violence while in prison.

In the second stage, the paradigm of handling children shifts to rehabilitation and improvement.
Various more humane efforts have emerged to deal with $\mathrm{ABH}$, for example starting from efforts to create a jail friendly child, rehabilitation of children who have committed crimes, and so on. Even though it is more humane, children are placed in the position of the guilty party so they must be rehabilitated. In the field of social work, this is like the phenomenon of blaming the victim. This paradigm has shortcomings because child criminals may be victims of an impartial system.

The last stage and what is now being applied in the SPPA Law is the paradigm of restorative justice. The spirit of restorative justice is to put the interests of children first as stated in the Convention on the Rights of the Child. It is in the interests of the child to continue to carry out their social functions. Receive education, free from all forms of violence and discrimination and able to maximize their potential. This social function can only be achieved by an $\mathrm{ABH}$ when the principles of restorative justice are carried out. In this paradigm, children are no longer viewed as merely the wrong party but also as the party whose rights must be fulfilled.

So far, the paradigm of handling $\mathrm{ABH}$ still uses the paradigm of retributive justice. This paradigm places children as passive parties and solely as legal objects. There is no systematic effort to improve children's behavior. Punishment for children is considered as the only way to deter children and become a good person, even though in reality it leaves many problems. However, this special treatment for $\mathrm{ABH}$ does not mean that there is preferential treatment for children, especially when compared to adults. However, it is more due to differences in needs so that the treatment that must be given is also different, for example the needs of adults in education may have been fulfilled, while children have not been fulfilled so that treatment of children cannot be the same as treatment of adults (Trihastuti \& Putri, 2020). The principle is to fulfill the needs of each person based on the principle of justice. Justice itself indicates the principle of equality for everyone to enjoy the widest possible range of the existing system. Rawls (1971) stated that each person is to have an equal right to the most extensive total system of equal basic liberties compatible with a similar system of liberty for all. So if an adult has the right to education, then a child is also entitled to an education. If an adult has the right to comfort, then a child also has the right to feel comfortable, and so on.

Due to the age difference between adults and children, the types of needs can be different even 
though they are still within one type of need, such as the need for security (Becroft, 2006). For adults, the need for security is not too difficult to obtain. Adults have had a stronger self-defense power. Meanwhile, the child still does not have adequate self-defense. When adults interact with each other, the social risk is low. However, when children interact with adults, the social risk is higher. Children can become victims of emotional abuse, sexual violence and even other physical violence. Therefore, for a child legal settlement outside the judicial system is a necessity to avoid these negative things. Settlement outside the judicial system was carried out by involving many parties, especially victims who usually filed lawsuits against $A B H$ (perpetrators) (Aji, 2019).

Therefore, restorative justice puts forward deliberation from the parties involved in legal cases. The goal is to jointly seek a fair solution based on the principle of restoring it to its original state. So it is not solely oriented to retaliation against criminals as applied in the retributive justice paradigm. To achieve this goal, what is called diversion is needed, namely the transfer of settlement of juvenile cases from the criminal justice process to the non-criminal court process. In our culture, this diversion is nothing but kinship deliberation.

Diversion is carried out with the objectives, among others: achieving peace between victims and children; resolve children's cases outside the court process; prevent children from being deprived of liberty; encourage the community to participate; and instill a sense of responsibility in children. Meanwhile, this diversion effort is carried out at three levels. First, at the investigation level, the police must undertake diversion efforts. Second, at the prosecution level (attorney's office) the diversion attempt must be made by the prosecutor. Third, at the court level diversion efforts must be made by the judge.

From this, it can be seen that restorative justice through a diversion process can be carried out at many levels, even from the police level when the case was just taking place. Because the neglect of children's rights so far is actually not only at the level of punishment, for example in prisons. There is a possibility of neglect during the investigation process at the police level. For example, when a child has to complete police statements such as an examination report, harsh and pressing questions can potentially cause trauma to the child. It may even be that the police station environment is scary enough for a child. At the police level, diversion must be attempted in order to achieve the best agreement for the fate of the child.

Furthermore, if forced to proceed to prosecution, diversion must also be pursued. In this context, the prosecutor's office is required to be sensitive to children's rights. A prosecutor must again seek diversion to the parties with the aim that the case does not proceed legally, even though this attempt has been made at the police level. Finally, if the case continues to trial, then the judge is also obliged to seek diversion. For example, by giving a decision to return to parents and/or other decisions based on the concept of restorative justice. Thus, with the existence of the SPPA Law, diversion with the aim of obtaining the best solution for the fate of children is possible at many levels. The aim is that as far as possible cases can be resolved outside the formal justice system.

As an effort, this diversion must be carried out even though it still opens the possibility for the parties to disagree on the diversion attempt, especially the victim's family. However, when agreed by the parties, the results of the diversion agreement can take the form of, among others: peace with or without compensation; return to parents/guardians; participation in education or training in educational institutions or LPKS (social welfare administering institutions) for a maximum period of 3 months; or community service. Thus, diversion efforts are made to achieve justice for the parties with the principle of restorative justice.

\subsection{At a Glance Social Work}

Social work is not a popular term known to the Indonesian people. As a scientific discipline, social work has long historical roots, especially in Britain and the United States. Then in its development, social work began to grow and develop in Indonesia around the 1960s. Despite its Western origin, the development of social work in Indonesia can find momentum. This is because, as a developing country, Indonesia still has a myriad of social problems that must be addressed seriously. Up until now the existence of social work in Indonesia needed efforts in order to develop social welfare. Social work here is intended as a professional activity, not a voluntary activity that can be done by anyone as widely understood by the wider community. Social work here is understood as a profession that aims to help individuals, groups and society in increasing or improving their capacity to function 
socially and create conducive social conditions to achieve these goals (Zastrow, 2009). Social problems become the main focus of social work, as well as health problems handled by the medical field, lack of knowledge by education, justice by law and so on.

As a professional activity, social work is supported by three important components, namely a body of knowledge, a body of skills and a body of values. As a professional field of science, social work has been supported by adequate educational institutions. The implementation of social work education has existed in various universities in Indonesia, both private and state universities. Not only undergraduate education (S1), several universities have organized postgraduate (S2) and even doctoral education. To mention some of them, namely, the University of Indonesia in Jakarta, the College of Social Welfare (STKS) in Bandung, Padjadjaran University in Bandung, Sunan Kalijaga State Islamic University in Yogyakarta, University of Muhammadiyah Malang in East Java and so on.

The main target in the social work sector is the Government of Social Welfare Services (PPKS), namely those who experience obstacles in carrying out their social functions so that they are able to fulfill their most basic life needs and therefore need social services (Suharto, 2007). Some community groups that can be categorized as PPKS include the poor, neglected children, street children, children or women who experience domestic violence, neglected elderly people, people with HIVIAIDS (PLWHA), informal sector workers, workers industries that don't get social security and so on.

To make it easier to understand social work, here are some of the main areas of work or setting that are often the places where social workers work (Suharto, 2007) include:

1. Family and child services with the task of family strengthening, family counseling, child care and adoption, daily care, prevention of neglect and domestic violence.

2. Health and rehabilitation: patient assistance in hospitals, community health development, mental health, vocational rehabilitation, rehabilitation of drug and alcohol addicts, mentoring PLWHA, harm reduction programs.

3. Community development: social planning, community organizing, neighborhood revitalization, environmental care, social forestry, strengthening social capital, strengthening the small economy.

4. Social security: social insurance schemes, social assistance, social funds, JKSM, social safety nets.

5. Emergency services: organization of assistance, crisis management, information and referrals, integration of refugees, development of community early warning.

6. School social work: school adjustment counseling, management of student behavior, management of tuition allowances, organizing student lunches, increasing family and community participation in education.

7. Industrial social work: employee assistance programs, handling stress and burnout, job placement and relocation, retirement planning, corporate social responsibility.

\subsection{Child Protection from a Social Work Perspective}

As stated in Law Number 23 of 2002, child protection is all activities to guarantee and protect children and their rights so that they can live, grow, develop and participate optimally in accordance with human dignity and protection from violence and discrimination. Thus, child protection is an effort to protect children's rights in a social, psychological and legal context. Child protection is increasingly needed for children who are in vulnerable conditions such as $\mathrm{ABH}$ (both as perpetrators, victims and witnesses).

Some data shows that ABH's rights are being neglected. During the period January 2005 - April 2006, the Samin Foundation found the facts that out of 17 children in conflict with the law being assisted, the majority of children were denied their rights. Of the 17 children, only 3 were not detained by the investigator. The rest are held in detention mixed with adults. As a result, children became increasingly depressed because they received bad treatment from adult prisoners. In addition, this mixing action actually provides an opportunity for children to "learn" from adult detainees regarding various criminal acts (Muchtar, 2006).

The rights of children to grow and develop should not be neglected, even if the child is suspected of committing a crime. Thus, in the context of social 
protection, children's rights must take precedence over other issues. This child's rights in the field of social work are like values that a social worker must hold in dealing with clients. One of the values related to children's rights and quite popular in social work is "self-determination" (Reamer, 1998), namely the decision or self-interest of a client which must be the main hold in addition to other values.

In other words, the interests and needs of children must be the main consideration. Putting the interests of the child first is clearly stated in the Convention on the Rights of the Child. Article 3 paragraph 1 of the Convention on the Rights of the Child states that in all actions concerning children, whether carried out by state or private social welfare institutions, courts, government officials and legislative bodies, the best interests of the child must be the main consideration (Crouch, 2019). It is in the best interest of the child that the child can function socially. Namely, they can carry out their functions as children: getting an education, fulfilling psychological needs, social needs with playmates and so on. Efforts to improve one's social functioning are also the main focus of social work (Thackeray et al., 1994).

It should be noted that social functioning is not only about fulfilling one's basic needs. However, it also relates to how a person can deal with shock and pressure. Suharto(2005) states that social function is the ability of people (individuals, families, groups or communities) and social systems (institutions and social networks) to meet/respond to basic needs, carry out social roles, and face shocks and stresses. As is well known, the shock and pressure will be faced by children who are faced with the law. It is this shock and pressure that a child should be able to avoid, or at least a child must have the ability to deal with these shocks and pressures (Castro \& Hernandez, 2019).

Social functioning also differentiates social work from other professions. Other professions, for example a doctor or psychologist treating patients, only focus on the patient's illness. However, for social workers, because they are based on this social function, the environment or social situation in which the client is located, including "significant others" must also be taken into consideration (Suharto, 2007). In the case of child protection, the main principle of social work is how the parties related to children must be concerned so that children's rights can be restored.

Child protection in the perspective of social work is a condition in which children in any condition can still carry out their social functions. In the context of $\mathrm{ABH}, \mathrm{a}$ child still has the right to get education, parental love, development, play, and avoid all forms of physical and non-physical violence. The right to carry out this social function must be the main consideration (Kokkalera et al., 2018). Social protection in the perspective of social work also reflects a view that does not make children the blame. Everyone, in the perspective of social work, is always influenced by the environment in which he lives and develops. This environment plays a role in shaping a person's personality and even influencing someone to do or not do something. In social work, this concept is known as person-in-environment (Zastrow, 2009). Person-in-environment indicates the existence of a system outside a person that influences one's life, such as the education system, family system, social service system, religious system, political system and so on.

When $\mathrm{ABH}$ is positioned as a party in this various system, in fact, a child who commits a crime can be caused by coercion or encouragement from outside parties. Therefore, it is very unfair if the child is positioned as the only party to be blamed, because in reality there are many factors that influence a child in committing a crime. Thus, social protection for children should be given by placing children not only in the wrong position so that they must receive punishment. Moreover, a child is known to have an unstable personality so that he is easily influenced by negative outsiders.

\section{RESULTS}

\subsection{ABH Situation in Indonesia}

As a country with a population of no less than 240 million people, Indonesia is faced with various social and legal problems, one of which is a crime. Criminality occurs due to intensive interaction between fellow citizens. In reality, this crime does not only happen to adults, but also to children. In cases of crime that befell children, the situation is different when the child has to face multiple problems. Besides having to deal with the law, a child must bear an uncertain future because he has to serve a sentence in detention (prison). This situation must receive special attention, because the transfer can have a deterrent effect, punishment will in fact leave new problems, namely obstruction of the future and development of children.

The problem of child crime has increased significantly from year to year. The National 
Commission for Child Protection (Komnas PA) noted that in the first quarter of 2012 alone there were 2,008 criminal cases committed by school-age children. The number includes various types of crimes such as theft, brawl and sexual harassment. Compared to previous years this number has increased. In 2010 there were 2,413 criminal cases of school-age children. The number then increased in 2011 , to 2,508 cases.

$\mathrm{ABH}$ in this paper does not only refer to the perpetrators, but also victims and witnesses. Even though in practice, what gets a lot of attention is in the context of the actors. As with the processes of child assistance in conflict with the law, most of them are carried out in the context of this perpetrator. Special assistance to the perpetrators cannot be blamed, because it is the perpetrator's side that causes the most problems. However, this does not mean that this is ignored on the side of both the victim and the witness. This is because both victims and witnesses are faced with the law. Traumatic problems can arise when you have to go through the examination process and even go to trial. This is where it is quite important to view $\mathrm{ABH}$ not only in the context of the perpetrator, but also the victim and witness.

Regarding $A B H$, especially in the context of the perpetrators, it is quite interesting to reveal the results of research conducted by the Samin Foundation in the Special Region of Yogyakarta. During the period January 2005 - April 2006, the Samin Foundation provided assistance to children who were suspected/accused/convicted of committing a crime. During this period, there were 17 children who became Samin clients scattered in the DIY and surrounding areas. They are generally suspected/charged/convicted of being involved in a criminal act in accordance with articles 290 and articles 362-363 of the Criminal Code and article 85 of Law no. 22 of 1997 on Narcotics. According to this study, most of the handling of $\mathrm{ABH}$ continued until the trial process. For example, in 2005, the Kulon Progo Police (one of the districts in Gunungkidul) handled 11 children as suspects. Of that number, only 3 children were not continued while the other 8 children were continued to the trial. However, out of 17 children accompanied by Samin, only 1 child was not detained/imprisoned (Muchtar, 2006).

In the case of assistance conducted by Samin, it shows that legal steps are used as the first and last alternative. There is no other alternative solution that is offered or pursued in order to resolve legal cases that befell children, even though before the birth of the
SPPA Law, the Convention on the Rights of the Child/CRC already regulates alternative solutions outside the court. The Convention on the Rights of the Child provides protection to children who are in special situations such as children victims of sexual crimes, children in conflict with the law, children in difficult situations, and children in situations of armed conflict. Meanwhile, regarding $A B H$ in article 37 of the $C R C$ and article 16 paragraphs 3 of Law no. 23 of 2002 concerning Child Protection states that the arrest, detention and punishment of children will be used only as a last resort (ultimum remidium) for the shortest and most appropriate period.

Since 1990, Indonesia has ratified the CRC, thus the CRC should be the basis for the fulfillment of children's rights, whether it is implemented in legislation or in practice. However, what is unfortunate is that the ratification was not followed by implementation in the field. There is still neglect of $A B H$ by making sentences in prison the only alternative solution. The absence of any alternative other than legal process since the ratification of the CRC is also shown by the data released by UNICEF. According to UNICEF data, in 2000 there were 11,344 children suspected of being the perpetrators of criminal acts. Meanwhile, in January - May 2002, 4,325 child prisoners were found in detention centers and correctional facilities throughout Indonesia. Even worse, the majority $(84.2 \%)$ of these children are in institutions of detention and prisons for adults. The number of children detained does not include children detained at the police station (Purnianti et al., 2002; Muchtar, 2006).

$\mathrm{ABH}$ who are treated in accordance with the CRC are in the minority, one that can be mentioned in the case that happened to AQJ recently. AQJ is the son of a famous musician, as it was known in October 2013, AQJ who was still underage drove a car and was involved in an accident that caused several deaths. $A Q J$ is considered negligent and causes others to die. What is interesting is, in the trial, AQJ was found guilty and the judge decided to give action to return $A Q J$ to the parents. Even in the trial process, AQJ was not detained but was allowed to stay at home. This case that befell AQJ may be an example of the implementation of the convention on children's rights by providing alternative solutions outside of punishment (prison or detention). Although it is also necessary to note that there are alternative solutions outside of this sentence, it does not mean that it is a justification for a child to commit a criminal act. 


\subsection{Children's Rights in the SPPA Law}

There are fundamental changes in SPPA compared to Law No. 3/1997 on Juvenile Court. This change, of course, more accommodates the rights of children in conflict with the law, from eliminating negative stigma, age of criminal coverage to the principle of restorative justice. Some of the fundamental changes that can be disclosed include: First, in the Juvenile Court Law in 1997 children who become criminals are called "naughty children", even this is explicitly stated in the Juvenile Justice Law. This mention has created a negative stigma against a child who commits a crime, even though a child who commits a crime could be the result of a victim from a system that is not child friendly (Steketee et al., 2019). For example, children who are victims of violence in the future can be motivated to do the same to other children. In addition, in some cases, the criminal act committed was only minor and it is possible to solve it out of court.

In the SPPA Law "naughty child" is replaced by the term "child who commits a crime". The replacement of this term actually does not only remove the negative stigma for children who commit criminal acts, but it is part of an effort to provide protection for children. Eliminating this negative stigma is also a form of effort to put children's interests first in order to get justice. As previously explained, children's interests must be the main consideration.

Second, there is the protection of children's rights. In article 3 of the SPPA Law, it guarantees children to get their rights properly. Such rights are (1) treated humanely with attention to the needs according to age; (2) the right to be separated from adults, both when detained and when forced to be in prison. This separation is to avoid negative impacts as mentioned in the previous review; (3) obtaining legal aid and other assistance effectively; (4) carrying out recreational activities; (5) free from torture, punishment or other cruel, inhuman and degrading treatment of dignity and status; (6) is not sentenced to death or life imprisonment; (7) is not arrested, detained or imprisoned, except as a last resort and for the shortest time; (8) obtaining justice before a juvenile court that is objective, impartial, and in hearings that are closed to the public; (9) identity is not published; (10) obtaining assistance from parents/guardians and people trusted by children; (11) obtain social advocacy; (12) obtain a personal life; (13) gain accessibility, especially for children with disabilities; (14) obtain education; (15) obtain health services; and (16) obtain other rights in accordance with statutory provisions.

Third, the age of criminal responsibility for children will be increased from 8 to 12 years. In the PA Law 1997 , the age of criminal responsibility for children is 8 until before the age of 18 years. The SPPA Law is revised to be 12 before the age of 18 years. This means that the SPPA Law basically seeks to accommodate children's rights by closing the possibility for children under 12 years of age to have criminal responsibility.

Article 21 of the SPPA Law states that in the case of a child under 12 years of committing or suspected of committing a criminal act, the investigator, social counselor and professional social worker make a decision to: (a) hand it back to the parent/guardian; or (b) participate in education, coaching and mentoring programs in government agencies or LPKS/ agencies dealing with social welfare, both at the central and regional levels, for a maximum of 6 (six) months.

The existence of this limitation is further tightened by the existence of an age limit for a child to get a sentence. Article 69 paragraph (2) states, children who are not yet 14 (fourteen) years old can only be subject to action. Actions that can be imposed on children include: (1) return to parents/guardians; (2) delivery to someone; (3) treatment in a mental hospital; (4) treatment at LPKS; (5) the obligation to attend formal education and/or training held by the government or private bodies; (6) revocation of driving license; and/or (7) corrections due to criminal acts.

Fourth, the SPPA Law introduces the principle of restorative justice as a way out for parties to settle legal cases out of court. The principle of restorative justice describes an attempt to put children's interests first. It is in the child's interest to carry out their social functioning. And this social functioning can only be maximally carried out when the problem of children is resolved out of court. The survival and development of children are prioritized in the principles of restorative justice. The application of restorative justice through a diversion process provides an opportunity for the parties involved to resolve problems by amicable deliberation. This method of settlement presupposes an appreciation for local culture. Because Indonesia has strong historical roots related to this deliberation. This is at least explicitly stated in one of the articles in Pancasila which is the philosophy of life as a nation and state. 


\section{DISCUSSION: IMPLICATIONS FOR SOCIAL WORK}

The concept of restorative justice in the SPPA Law as described above has a significant impact on the field of social work. This is due to a shift from a formal legal process to a settlement that is familiar in nature. The implications for social work include: First, there is a demand for a greater role from social workers. Social workers are required to advocate for $\mathrm{ABH}$ so that their rights can be fulfilled in accordance with the SPPA Law. In addition, more specifically, the role of social workers is needed in the diversion process. Together with children, parents/guardians, victims, community counselors, social workers, conduct deliberations to reach an agreement as fair as possible in the case at hand.

In cases involving $\mathrm{ABH}$ so far, social workers have only played a minor role. When $\mathrm{ABH}$ enters the trial process and gets a sentence, social workers no longer have a free space to carry out their duties. However, the principle of restorative justice requires social workers to be involved intently, starting from the diversion process to their role in the Social Welfare Organizing Institution (LPKS).

As explained above, the diversion process can be carried out at three levels, namely the police (investigation), the prosecutor's office (prosecution) and the judiciary (court decisions). It is at these three levels that diversion must be carried out by involving social workers. Article 8 of the SPPA Law states: (1) The diversion process is carried out through deliberation involving children and their parents/guardians, victims and/or their parents/guardians, community counselors, and professional social workers based on a restorative justice approach; (2) If necessary, the deliberation as referred to in paragraph (1) may involve social welfare workers and/or the community. It is clearly stated here that the role of social workers in the diversion process. This role can take various forms, such as emotional reinforcement or mediation in order to find the best solution for the child.

In fact, specifically, the SPPA Law mentions the various tasks of social workers related to $\mathrm{ABH}$. Article 68 states that social workers have the following duties:

1. Guiding, helping, protecting, and accompanying children by conducting social consultations and restoring children's self-confidence.
2. Providing social assistance and advocacy.

3. Being children's friends by listening to children's opinions and creating a conducive atmosphere.

4. Helping the recovery process and changing children's behavior.

5. Making and submitting reports to the Community Guidance regarding the results of guidance, assistance and guidance for children based on a court decision being sentenced to a criminal or action.

6. Providing considerations to law enforcement officials for handling children's social rehabilitation.

7. Accompanying the delivery of children to parents, government agencies, or community institutions.

8. Approaching the community so that they are willing to accept children back in their social environment.

Second, the bigger role of social workers must be followed by an increase in quality and quantity. In terms of quality, social workers are required to have knowledge and skills related to $A B H$ issues, for example their understanding of the SPPA Law, the Child Protection Law and related laws. Regarding skills, for example, social workers must be equipped with the ability to deal with clients who have experienced trauma and how to deal with them. So, the implication is that social welfare service institutions that shelter social workers are required to provide this quality improvement, both in terms of education and training.

In terms of quantity, a larger number of social workers is needed in handling $\mathrm{ABH}$. For now, there are 72 social workers who come from the government and specifically handle $\mathrm{ABH}$ from the Child Protection Social Worker Service Unit (Sakti Peksos PA) with a total of 650 people. This number must be increased again so that outreach in $\mathrm{ABH}$ cases can be more optimal. Increasing the quantity and quality of social workers can be done by intensifying the implementation of social work education, which has been in existence in several universities (public and private). In addition, training or seminars can also be carried out to support social workers' knowledge regarding $\mathrm{ABH}$. The certification process, which has 
been running so far, must also be carried out to improve the quality and quantity of social workers. However, what is even more crucial is the need for commitment from the government regarding the budget, both for incentives for social workers or for organizing activities in order to improve the quality and quantity of these social workers.

Third, it is necessary to strengthen social service institutions. As stated in the SPPA Law, there are several social service institutions that need to be prepared as a consequence of the realization of the principles of restorative justice. For example, LPKA (Special Development Institution for Children), which functions as a place for children to undergo their criminal period; LPAS (Temporary Child Placement Institution) as a temporary place for children during the judicial process; and LPKS (Social Welfare Organizing Institutions) as a place for social services that carry out social welfare for children.

These institutions have a crucial role in handling $\mathrm{ABH}$. Like the LPKS which has been mandated to the Ministry of Social Affairs as a ministry that plays a role in the implementation of social welfare. The LPKS itself can basically take advantage of the roles and functions of existing institutions such as the PSMP (Panti Sosial Pamardhi Putra), RPSA (Children's Social Protection House), PSBR (Bina Youth Social Institution), and PSAA (Children's Social Institution). For example, PSMP which can carry out functions as social protection and rehabilitation of $\mathrm{ABH}$ has existed in several places, namely 4 managed by the Central Government and 4 managed by the Regional Government; There are 25 RPSAs that function to provide services to children who need special protection (including $\mathrm{ABH}$ ) throughout Indonesia.

With the application of the principle of restorative justice in the SPPA Law, the existence of this LPKS must be optimized, although some deficiencies still occur here and there. In the "rapid identification" that was carried out in July 2014 regarding the readiness of the government, local government and the community in implementing the SPPA Law, it showed that there was an inadequate condition, especially related to LPKS facilities and infrastructure. This is understandable because infrastructure requires a lot of money. Meanwhile, local governments themselves are not ready to share funding related to the implementation of this LPKS. However, in general, LPKS implementing human resources are ready (Ministry of Social Affairs, 2014). These are at least some of the impacts that must be prepared for the social work sector for the enactment of the SPPA Law.

\section{CONCLUSIONS}

The findings demonstrated that insofar the rights of children in conflict with the law $(\mathrm{ABH})$ have so far been neglected. This is because laws and regulations are still not taking sides. However, with the enactment of the 2012 SPPA Law, the rights of $\mathrm{ABH}$ that have been neglected can experience improvement. This is because the SPPA Law allows $A B H$ to resolve problems outside the court with the principle of restorative justice. Restorative justice is known as a new principle that does not exist in the CL Act.

The findings revealed the theoretical implication that restorative justice is different from retributive justice as applied in the previous Law (Children's Court). Restorative justice views children as parties whose rights must be fulfilled, be it educational, social, or psychological rights. The fulfillment of children's rights must take precedence over other actions. This is in line with the Convention on the Rights of the Child, which mandates that the interests of children are prioritized over other interests. Practically, restorative justice is implemented in the presence of diversion attempts or in our society's culture is family deliberation. Diversion as an effort that must be carried out at the police, prosecutors and judiciary levels has implications for social work. The implication is in the form of strengthening human resources (social workers) both in quality and quantity, because in the diversion process the role of social workers is central enough to reach solutions to legal cases faced by $\mathrm{ABH}$. Another implication is in the institutional sector, with the need for social welfare service institutions to accommodate $\mathrm{ABH}$. In this institutional sector, readiness must also be followed in terms of management, budget, and human resources so that the transfer of $\mathrm{ABH}$ handling from formal legal institutions to social service institutions can run smoothly.

As for recommendations, there needs to be a mutual understanding between the community, government, police, prosecutors and judiciary regarding the SPPA Law. This understanding can be achieved through massive outreach programs on the part of the government and also by improving the quality of social workers. It also needs the participation of social workers who handle $\mathrm{ABH}$ to require broader knowledge or skills by encouraging social work education or training can be undertaken to meet this 
need. In term of the increased quantity of social worker, the enactment of the SPPA Law requires more social workers to provide assistance. The government can recruit more social workers related to $\mathrm{ABH}$ to increase the quantity of social workers. It needs the strengthening Social Welfare Organizing Institutions (LPKS). Strengthening needs to be done both in terms of management, human resources and budget. To strengthen the role of LPKS in each region, local governments must fully support, especially in terms of funding. Because it is related to LPKS, one of its shortcomings is the limited facilities and infrastructure. So, it needs to be supported by local governments so that the SPPA Law can be realized without any significant obstacles.

\section{REFERENCES}

Aji, W. S. (2019). The Implementation of Diversion and Restorative Justice in the Juvenile Criminal Justice System in Indonesia. Journal of Indonesian Legal Studies, 4(1), 73.

Amanda, P. K. (2014). AQJ dan Peradilan Pidana Anak. Kompas, Aug 8, 2014.

Becroft, A. J. (2006). Children and young people in conflict with the law: Asking the hard questions. Juvenile and Family Court Journal, 57(4), 1-37. https://doi.org/10.1111/j.1755-6988.2006.tb00129.x

Castro, E. T., \& Hernandez, A. A. (2019, March). Developing a Predictive Model on Assessing Children in Conflict with the Law and Children at Risk: A Case in the Philippines. In 2019 IEEE 15th International Colloquium on Signal Processing \& Its Applications (CSPA) (pp. 243-248). IEEE. https://doi.org/10.1109/CSPA.2019.8695984

Crouch, M. (Ed.). (2019). The Politics of Court Reform: Judicial Change and Legal Culture in Indonesia. Cambridge University Press. https://doi.org/10.1017/9781108636131

Davies, S. G., \& Robson, J. (2016). Juvenile (In) justice: Children in Conflict with the Law in Indonesia. asia-pacific journal on human rights and the law, 17(1), 119-147. https://doi.org/10.1163/15718158-01701009
John, R. (1971). A theory of justice. Cambridge, Harvard University Press.

Khair, S. (2001). Street children in conflict with the law: The Bangladesh experience. Asia-Pac. J. on Hum. Rts. \& L., 2, 55. https://doi.org/10.1163/15718150120954876

Kokkalera, S. S., Marshall, C. E., \& Haen Marshall, I. (2018). The role of parental maltreatment and parental social control on self-reported violent offending in Indonesia and the US: Does gender make a difference? Societies, 8(2), 33. https://doi.org/10.3390/soc8020033

Law No. 3 of 1997 on Juvenile Court

Law Number 11 of 2012 concerning the Child Criminal Justice System

Ministry of Social of the Republic of Indonesia. (2014). Rapid Identification regarding the Readiness of Government, Local Government and Society in Implementing Law Number 11 of 2012. Jakarta: Ministry of Social of the Republic of Indonesia.

Muchtar, F. (2006). Situasi Anak Yang Berkonflik Dengan Hukum Di Daerah Istimewa Yogyakarta \& Semarang. Samin Yayasan Setara.

Purnianti, Supatmi, M. S., \& Tinduk, N. M. M. (2002). Analisa situasi sistem peradilan pidana anak (juvenile justice system) di Indonesia. Jakarta: Unicef Indonesia.

Reamer, F. G. (1998). Social work values and ethics. New York: Columbia University Press.

Steketee, M., Aussems, C., \& Marshall, I. H. (2019). Exploring the impact of child maltreatment and interparental violence on violent delinquency in an international sample. Journal of interpersonal violence, 0886260518823291 https://doi.org/10.1177/0886260518823291

Suharto, E. (2005). Membangun Masyarakat Memberdayakan Rakyat Kajian Strategis Pembangunan Kesejahteraan Sosial dan Pekerjaan Sosial. Bandung: Refika Aditama.

Suharto, E. (2007). Pekerjaan Sosial di Dunia Industri (Memperkuat Tanggung Jawab Sosial Perusahaan). Bandung: Refika Aditama.

Thackeray, M. G., Farley, O. W., \& Skidmore, R. A. (1994). Introduction to social work. New York: Appleton-Century Crofts.

Trihastuti, N., \& Putri, S. A. (2020). Reposition of child protection through the enforcement of human rights and constitutional rights. Jurnal Hukum dan Peradilan, 9(2), 314-335. https://doi.org/10.25216/jhp.9.2.2020.314-335

Zastrow, C. (2009). Introduction to social work and social welfare: Empowering people. Cengage Learning.

Received on 15-02-2021

Accepted on 21-04-2021

Published on 26-04-2021

https://doi.org/10.6000/1929-4409.2021.10.104

(C) 2021 Edi Suharto; Licensee Lifescience Global.

This is an open access article licensed under the terms of the Creative Commons Attribution Non-Commercial License (http://creativecommons.org/licenses/by-nc/3.0/) which permits unrestricted, non-commercial use, distribution and reproduction in any medium, provided the work is properly cited. 